\title{
Joanna Sosnowska, Opieka nad dziećmi w Lodzi w latach I wojny świato- wej, Wydawnictwo Uniwersytetu Łódzkiego, Łódź 2017, ss. 495
}

$\mathrm{J}$

oanna Sosnowska, adiunkt w Katedrze Historii Wychowania i Pedeutologii na Wydziale Nauk o Wychowaniu Uniwersytetu Łódzkiego, po opublikowaniu w 2011 r. znakomitej monografii pt. Działalność socjalna i opiekuńczo-wychowawcza Łódzkiego Chrześcijańskiego Towarzystwa Dobroczynności (1885-1940), w 2017 r. wydała kolejną pozycję z zakresu historii społecznej ze szczególnym uwzględnieniem kwestii opieki nad dziećmi w Łodzi, w latach okupacji niemieckiej, w czasie I wojny światowej. Wybór tematu recenzowanej pracy jest niezwykle trafny, bowiem sytuacja społeczności łódzkiej w latach I wojny światowej była bardzo trudna, nie znajdująca porównania z innymi ośrodkami miejskimi, w tym z Warszawą, okupowanej przez Niemcy części Królestwa Polskiego. Trafność wyboru problemu badawczego z zakresu historii wychowania wynika również z faktu, że w dotychczasowej literaturze przedmiotu brak odrębnego opracowania obejmującego zagadnienie opieki nad dziećmi w Łodzi w dramatycznych latach I wojny światowej.

Łódź, drugie co do wielkości po Warszawie miasto na ziemiach polskich, a przede wszystkim największy ośrodek przemysłowy tego obszaru, zostało potraktowane przez władze niemieckie w sposób brutalny. Otóż od początku okupacji, a szczególnie w latach 1916-1918, Niemcy prowadzili planową dewastację i grabież łódzkiego przemysłu. Odbywała się ona poprzez rekwizycje surowców, gotowych towarów i maszyn, przymusowy zakup towarów wg narzuconych cen, wywłaszczenia i konfiskaty. Szczególnie dramatyczna dla łódzkiego przemysłu była akcja demontażu maszyn, celem wydobycia z nich metali kolorowych, konfiskata silników, pasów transmisyjnych, rur i innych części. Warto dodać, że wywieziono większość maszyn z największych zakładów przemysłowych: K. Scheiblera, I.K. Poznańskiego, L. Geyera, L. Grohmana, Widzewskiej Manufaktury i wielu innych. Polityka dewastacji przemysłu włókienniczego w Łodzi i okręgu łódzkim miała na celu pozyskanie przez Niemców niezbędnych towarów i surowców, jak również zniszczenie przemysłu tekstylnego Królestwa Polskiego, ewentualnego konkurenta w przyszłości dla przemysłu Rzeszy.

Powyższa polityka władz okupacyjnych wobec łódzkiego przemysłu doprowadziła do jego unieruchomienia. Już w okresie do maja 1915 r. bez pracy i środków do życia pozostawało ponad 250 tys. łodzian. Trudna sytuacja ekonomiczna 
spowodowała znaczny odpływ ludności z Łodzi. W latach 1914-1918 liczba mieszkańców miasta, która liczyła ponad 600 tys. (wraz z włączonymi do Łodzi w 1915 r. Bałutami i Chojnami) zmniejszyła się o ponad 43\% do około 342 tys. osób. Bezrobocie i brak środków do życia większości mieszkańców Łodzi towarzyszyły przez cały okres wojny. W szczególnie trudnej sytuacji były dzieci łódzkich, biednych rodzin robotniczych, które wymagały opieki w związku z powszechnym głodem, katastrofalną sytuacją higieniczną i zdrowotną oraz w zakresie oświaty na poziomie elementarnym. Wymienione wyżej zagadnienia stały się podstawowymi problemami, które przedstawiła w swojej książce J. Sosnowska.

Na szczególne podkreślenie zasługuje wykorzystanie przez autorkę źródeł i literatury. Warto dodać, że J. Sosnowska zebrała niezwykle obszerne materiały archiwalne z 8 zespołów w Archiwum Państwowym w Łodzi oraz Archiwum Archidiecezjalnym w Łodzi, łącznie 194 teczki z Akt m. Łodzi, Głównego Komitetu Obywatelskiego w Łodzi, Łódzkiego Chrześcijańskiego Tow. Dobroczynności, Parafii i Stowarzyszeń Łódzkiej Diecezji Ewangelicko-Augsburskiej, Tow. Opieki nad Matką i Dzieckiem „Kropla Mleka”, Tow. Opieki nad Dziećmi „Gniazdo” w Łodzi, Akt Dekanatu Łódzkiego oraz Akt Kurii Diecezjalnej Łódzkiej. Ponadto źródła drukowane w postaci dokumentów normatywnych ówczesnych władz okupacyjnych, jak również sprawozdania wielu organizacji społecznych działających w latach 1914-1918 w Łodzi oraz prasę i wydawnictwa periodyczne. Poza obszernymi materiałami źródłowymi, autorka wykorzystała imponującą liczbę około 600 pozycji z zakresu literatury historycznej, obejmującej dzieje Łodzi, jak również publikacje z historii wychowania, historii oświaty oraz opieki zdrowotnej.

Całość recenzowanej książki składa się, poza obszernym wstępem i zakończeniem, z sześciu rozdziałów. W pierwszym, który został poświęcony warunkom życia ludności Łodzi w latach I wojny światowej, autorka przy wykorzystaniu obszernej już literatury historycznej oraz źródeł archiwalnych, przedstawiła kolejno następujące zagadnienia: tzw. operacja łódzka i okupacja niemiecka od 6 grudnia 1914 r.; sytuacja gospodarcza mieszkańców miasta; zmiany liczebności oraz struktury narodowościowo-wyznaniowej łodzian; sytuacja materialna i zdrowotna ludności Łodzi; kwestia społeczno-prawna dzieci i postulaty w zakresie opieki nad najmłodszymi mieszkańcami miasta. Wszystkie te problemy zostały przez autorkę opracowane bardzo obszernie, szczegółowo i obiektywnie.

W drugim rozdziale J. Sosnowska zajęła się działalnością w zakresie opieki, wychowania oraz ochrony zdrowia wśród najmłodszych łodzian ze strony władz miejskich. W pierwszej części tego rozdziału autorka przedstawiła działalność powstałego już w sierpniu 1914 r., zaraz po wybuchu wojny, Głównego Komitetu Obywatelskiego miasta Łodzi, który działał do czerwca 1915 r., kiedy władzę w mieście przejął Magistrat powołany przez Niemców. GKO m. Łodzi powołał trzy sekcje, które zajmowały się pomocą dla dzieci. Były to: Sekcja Sanitarno-Szpitalna, Sekcja Szkolna oraz Komitet Tanich i Bezpłatnych Kuchni. Po likwi- 
dacji GKO i powołaniu Magistratu, działalność w zakresie pomocy dla dzieci przejęły władze miasta. W tym celu przy Magistracie powołano trzy wydziały, które zajmowały się najmłodszymi mieszkańcami Łodzi. Pierwszy z nich to Wydział Niesienia Pomocy Biednym, który poprzez kilka podległych wydziałowi oddziałów udzielał potrzebującym zasiłków pieniężnych, zaopatrywał ubogich mieszkańców miasta w żywność i odzież, organizował tanie kuchnie, opiekę w przytułkach, sierocińcach i ochronkach oraz przekazywał fundusze dla organizacji społecznych i dobroczynnych. Drugą jednostką był Wydział Zdrowotności Publicznej, którym kierował znany łódzki lekarz dr Henryk Trenkner. Wydział ten dzielił się na dwa oddziały: Sanitarno-Lekarski, którym kierował dr Stanisław Skalski, a zadaniem tego wydziału było zapobieganie i walka z chorobami zakaźnymi poprzez powszechne szczepienia oraz kontrolę stanu sanitarnego miasta. Z kolei drugi, Oddział Szpitalno-Gospodarczy, zajmował się zarządzaniem łódzkimi szpitalami i przychodniami.

Trzecią jednostką Magistratu m. Łodzi był Wydział Szkolnictwa, którego działalność autorka ocenia pozytywnie, szczególnie po akcie 5 listopada 1916 r. Ogółem w latach 1915-1918 liczba szkół elementarnych miejskich wzrosła z 68 do 142 placówek. Całość rozdziału trzeciego należy ocenić bardzo wysoko, autorka bowiem na podstawie obszernych źródeł w sposób niezwykle szczegółowy przedstawiła działalność opiekuńczą nad dziećmi ze strony Magistratu m. Łodzi.

Rozdział czwarty recenzowanej książki J. Sosnowskiej obejmuje działania na rzecz dzieci łódzkich organizacji filantropijno-społecznych. Autorka skupiła się na przedstawieniu pomocy dla dzieci ze strony Łódzkiego Chrześcijańskiego Tow. Dobroczynności, które generalnie od momentu powstania w 1885 r. zajmowało się ubogimi (także dorosłymi) oraz organizacji wyłącznie działających na rzecz dzieci, którymi były: Towarzystwo „Kropla Mleka” w Łodzi, jak również Towarzystwo Opieki nad Dziećmi „Gniazdo Łódzkie”. Łódzkie Chrześcijańskie Tow. Dobroczynności pomagało przede wszystkim dzieciom z ubogich rodzin robotniczych, sierotom i półsierotom głównie poprzez prowadzenie ochronek, szkół elementarnych, kolonii letnich, jak również poprzez wspieranie szpitala dziecięcego Anny-Marii. Natomiast Towarzystwo „Kropla Mleka”, które powstało jeszcze w 1904 r. w Łodzi i w okresie przed wybuchem wojny zajmowało się przede wszystkim opieką higieniczno-lekarską nad niemowlętami oraz propagowało zasady higieny wśród matek, w czasie wojny, poza tymi działaniami, zajęło się także dożywianiem dzieci oraz wspomagało karmiące matki. W latach 1914-1918 w Łodzi działało 11 punktów rozdawnictwa mleka świeżego oraz skondensowanego, jak również kaszy i innych artykułów żywnościowych.

Z kolei Tow. Opieki nad Dziećmi „Gniazdo Łódzkie”, które powstało w $1907 \mathrm{r}$. z inicjatywy łódzkich lekarzy i duchownych wyznań chrześcijańskich, w czasie wojny już w listopadzie 1914 r. w wyniku bombardowania w czasie tzw. „operacji łódzkiej”, straciło swój lokal, w którym mieścił się sierociniec przy ul. Radwań- 
skiej. Mimo to „Gniazdo Łódzkie” w okresie wojny prowadziło kilka placówek opiekuńczych. Rozdział czwarty, podobnie jak poprzednie, został opracowany bardzo szczegółowo i konsekwentnie w odniesieniu do omawianych problemów.

$\mathrm{W}$ rozdziale piątym autorka przedstawiła działania opiekuńcze wobec dzieci prowadzone przez wspólnoty chrześcijańskie. Wśród łódzkich katolików najbardziej aktywne było Tow. Schronisk św. Stanisława Kostki, którego twórcą i prezesem był proboszcz kościoła pod wezwaniem św. Stanisława Kostki ks. Wincenty Tymieniecki (pierwszy łódzki biskup już w II Rzeczypospolitej). Towarzystwo to prowadziło 8 ochronek dla biednych dzieci, trzy przytułki dla sierot oraz szkołę dla głuchoniemych. Pozostałe parafie katolickie, w liczbie sześciu, zorganizowały 12 ochronek oraz 6 tanich kuchni.

Kolejną wspólnotą chrześcijańską byli mariawici skupieni w czterech parafiach. Ich działalność opiekuńcza obejmowała 5 ochronek, 5 szkół elementarnych, 4 sale różnorodnych zajęć. Opiekę nad dziećmi organizowano również w 3 domach parafialnych oraz 3 domach ludowych. Łódzcy protestanci skupieni w dwóch parafiach ewangelicko-augsburskich - św. Trójcy i św. Jana - z inicjatywy pastora ks. Rudolfa Gustawa Gundlacha i ks. Wilhelma Piotra Angersteina zorganizowali 7 ochronek, 2 tanie kuchnie, dom sierot wraz ze szkołą, przytułek dla bezdomnych dzieci wyznania ewangelickiego oraz Dom Sierot Wojennych. Nieliczna (ok. 6 tys. osób) zbiorowość prawosławna w latach I wojny światowej prowadziła dwie instytucje opiekuńcze dla dzieci, były to przytułek przy cerkwi św. Olgi oraz tzw. kuchnia dzienna. W rozdziale piątym, podobnie jak to ma miejsce w całej pracy, autorka niezwykle szczegółowo opracowała poszczególne zagadnienia.

W ostatnim, szóstym rozdziale, J. Sosnowska bardzo obszernie przedstawiła działalność organizacji i instytucji pomocowych dla dzieci licznej (ok. 34\% ogółu mieszkańców) społeczności żydowskiej. Autorka zwróciła uwagę, że łódzcy Żydzi już od lat 80. XIX w. tworzyli organizacje zajmujące się dziećmi z biednych rodzin oraz sierotami. Przed 1914 r. w Łodzi funkcjonowały następujące żydowskie instytucje pomocowe dla dzieci: Tow. Kolonii Letnich dla Dzieci Żydowskich m. Łodzi; Łódzkie Żydowskie Tow. Opieki nad Sierotami; Tow. Niesienia Pomocy Biednym Dzieciom Wyznania Mojżeszowego; Ochrona dla Dziewcząt Wyznania Mojżeszowego im. małżonków J. i A. Hertz; Łódzki Żydowski Dom Sierot, który w czasie wojny przekształcono w Przytulisko dla Dzieci Wyznania Mojżeszowego; Schronisko dla Dzieci Wyznania Mojżeszowego. Natomiast w latach I wojny światowej miejscowi Żydzi powołali jeszcze 9 instytucji opiekuńczych. Były to: Przytułek Tow. Opieki nad Sierotami i Dziećmi Rezerwistów; Żydowska Ochrona Ludowa przy Towarzystwie „Przyjaciel Dzieci”; Zakład Freblowski i Szkółka „Szalom Alejchem” przy Tow. Żydowski Dom Ludowy „Bet-Am”; Kuchnia Dziecięca nr 62 przy Żydowskim Tow. „Pomoc”; Kuch- 
nia Dziecięca nr 48 Tow. Zwolenników Niesienia Pomocy Biednym Dzieciom Żydowskim; wspomniane już Przytulisko dla Dzieci Wyznania Mojżeszowego; Łódzki Żydowski Dom Sierot Starego Miasta; Ochronka „Herclija” Komitetu Syjonistycznego; Przytułek dla Dzieci Bezdomnych i Sierot przy Gminie Starozakonnych. Jak wynika ze szczegółowych rozważań autorki pomoc dla biednych dzieci i sierot wyznania mojżeszowego została zorganizowana najpełniej. Łódzkie środowisko żydowskie, w porównaniu ze społecznością polską i niemiecką, przeznaczało najwięcej środków finansowych na opiekę nad dziećmi z biednych rodzin starozakonnych.

Publikację J. Sosnowskiej oceniam bardzo wysoko, stanowi ona znakomite uzupełnienie historii Łodzi oraz historii społecznej ziem polskich w latach I wojny światowej. Uważam, że autorka zbyt skromnie zalicza swoją książkę do tzw. mikrohistorii i badań regionalnych. Otóż jest dla mnie oczywiste, iż publikacja ta, obejmująca dzieje społeczności drugiego co do wielkości miasta na ziemiach polskich i największego ośrodka przemysłowego tego obszaru w latach Wielkiej Wojny jest ważną częścią historii Polski, a nie tylko regionu łódzkiego.

Wiestaw Puś Uniwersytet Łódzki, Wydziat Filozoficzno-Historyczny 